\title{
New government, old problems
}

The surprise re-election of the Conservative British government may not be as bad for British science as the past decade would suggest. Much will depend on new people's willingness to listen to the truth.

AGAINST the bookmakers' odds and the confident predictions of the commercial polling organizations, the British government was re-elected last week. Although its majority is small, it is enough to keep it in office for a full five years. On the face of things, that is bad news for the British research enterprise. Why should a government convinced that it has done as well by science as anybody could have expected now change its view, especially after an electoral upset?

Luckily, there is some hope. The Prime Minister, Mr John Major, has been speaking of a government "of all the people"; the hope must be that even researchers and academics are counted among them. Then, as is customary, there is a change of faces at the two ministries with an important influence on research. Mainlandminded Mr Michael Heseltine, with hankerings after industrial policy (or public support for chosen innovation), will run the Department of Trade and Industry (DTI). And Mr John Patten, previously at the Home Office, becomes the sixth Secretary of State for Education and Science in twelve years; the hope is that, with a Cambridge $\mathrm{PhD}$ and a spell as an Oxford academic, he will at least acknowledge that there is a problem to be tackled. If he plays his cards well, he may yet collect the honorary degree Oxford's academics denied to Mrs Margaret Thatcher a decade ago. Certainly, neither of the new men needs feel bound by the complacency of his predecessor.

The diagnosis is now well-known: British researchers are mostly demoralized, underpaid and inadequately supported in research, while the institutions in which they work (universities and public research organizations) are so much in flux that opportunities for long-term programmes of research have dwindled. Demoralization, being a state of mind, cannot confidently be measured objectively, although there are putative proxies - emigrant inclinations, for example. But Patten (for it is his responsibility) should be readier than his predecessors to listen to what researchers say. As the whole world knows, people are most easily further demoralized by being told that their assessment of their own states of mind must be imagined.

It also falls to Patten to promise a measure of stability for the British system of research support. Three important changes are now under way [em] the transfer of a chunk of the collective recurrent budget of the universi- ties to the research councils (which will then accompany research grants with overhead payments), the designation of polytechnics as universities and the balkanization of the system of university support (with separate funding councils for Scottish and Welsh higher education). It remains to be seen what scope there will be for institutional self-improvement under the new overhead arrangements, the redesignation of polytechnics is welcome but precipitate and the balkanization of funding arrangements a needless concession to regional ambitions that oddly conflicts with Major's passionate defence of the integrity of the Union (of the United Kingdom) during the election campaign. Patten could do worse than promise that this will be an end to structural change for the time being.

At some stage, he will also have to find more money, and be content that most of it should be spent on salaries. It is absurd that the chief avenue of recruitment into British research should require $\mathrm{PhD}$ students to subsist on less than half the income of a stenographer, but at present there is no choice; students might otherwise be earning more than those who teach them. The research community could help Patten (and itself) by hammering out a tolerable mechanism'for deciding researchers' pay. But that will not pay for more research, which is where Heseltine has a role to play. DTI is traditionally responsible for British representation at Brussels, which has more money than good ideas. If Heseltine were to push for a European Community research programme functioning as a grant-making agency, he would win many friends and do a lot of good.

\section{Healy in a hurry}

Dr Bernadette Healy has rid the Human Genome Project of Dr J. D. Watson in a distasteful way.

DR James D. Watson, co-discoverer (with F. H. C. Crick) of the structure of DNA, director of the Cold Spring Harbor Laboratory and of the US Human Genome Project, can be an awkward customer. Unsurprisingly. He has strong opinions. He usually knows what he wants. He is often right. Dr Bernadette Healy, director of the US National Institutes of Health (NIH) for the past year, also has strong opinions and seems to know what she wants. It has been plain for some time that she has wanted 